\title{
Snowball Throwing: An English Learning Method to Improve Vocabulary Mastery and Psychomotor Ability
}

\author{
Syams Kusumaningrum ${ }^{1}$, Irna Ganda Setyawati ${ }^{2}$, Anam Sutopo ${ }^{3}$, Koesomo Ratih, Taha \\ Ibrahim Ahmad Badri, Ku Ares Tawandorloh \\ ${ }^{1,2}$ Faculty of Teacher Training and Education, Universitas Pendidikan Muhammadiyah So- \\ rong, Indonesia \\ ${ }^{3,4}$ Faculty of Teacher Training and Education, Universitas Muhammadiyah Surakarta, Indo- \\ nesia \\ ${ }^{5}$ Faculty of Language and Translation, Al Azhar University, Egypt \\ ${ }^{6}$ Faculty of Humanities and Education, Fathoni University, Thailand
}

DOI: 10.23917/ijolae.v2i1.8973

Received: October $4^{\text {th }}, 2019$. Revised: October $23^{\text {th }}, 2019$. Accepted: October $25^{\text {th }}, 2019$

Available Online: October $26^{\text {th }}, 2019$. Published Regulary: January $1^{\text {st }}, 2020$.

\begin{abstract}
Vocabulary and psychomotor abilities are two important things in learning English especially for elementary school students. In mastering these two competencies we need a learning strategy that is not only able to explain but also to describe and illustrate. Snowball throwing is a learning method that uses a paper which contains a word that is shaped like a ball. This method is usually used in learning English. This research tries to find out the influence of the snowball throwing method towards students' vocabulary mastery and psychomotor ability in learning English in the first grade of SD Islam Terpadu Sorong City. The research is quasi-experimental by using randomized pre-post control group design. The subject of this research consists of two groups; experiment and control groups have 27 students in each. There are two instruments in this research; they are the test for English vocabulary and psychomotor ability. The data are examined by using a non-parametric tests such as Mann Whitney U dan Wilcoxon signed ranks. Related to the result of the hypothesis test towards the two paired samples, we can find that the score of English vocabulary mastery $(\mathrm{p}=$ $0,000)$ and psychomotor ability $(\mathrm{p}=0,016)$ are significant, where the significance score of experiment group is lower than the critical limit of the research 0,05 . So, we can conclude that the snowball throwing method influences significantly towards students' vocabulary mastery and psychomotor ability at the first grade of SD Islam Terpadu Sorong City. This research shows that snowball throwing method can be used to improve students' vocabulary mastery and psychomotoric ability in English subject.
\end{abstract}

Keywords: snowball throwing, vocabulary mastery, psychomotor ability

Corresponding Author:

Syams Kusumaningrum, Faculty of Teacher Training and Education, Universitas Pendidikan Muhammadiyah Sorong, Indonesia

e-mail: syams.bing@gmail.com

\section{Introduction}

Mastering English is really important nowadays, not only for adults but also for young students. They learn English to know more about the world. There are so many aspects in learning English such as grammar, vocabulary, and pronunciation (Burn, et al, 2015). As one of the important aspects in learning English, vocabulary can be the first step in mastering and communicating in English (Alderson \& Bachman, 2000).

English vocabulary mastery is needed by children. At the age of 2 until 7, they face their pre-operational stage (Paul, 2011). This stage is based on the development of intuitive thinking and semiotic function or symbol (Padmanabha, 2018). It means that the 
active and concrete learning method such as game and play is effective to be implemented in this age (Gilman, 2012). The data from NAEYC (National Association For The Education Of Young Children) in 2006 said that children at the level of kindergarten are appropriate to be exposed with a concrete behaviour that includes an active and fun learning habitual action (Khanifatul, 2014).

The first level of education is important to make sure that children can evolve optimally based on their development stage. In this stage, they can learn quickly about norm and value through simple analogies which are associated with a figure or certain game (Berger \& McLanahan, 2015). The learning method by using games can be used to train their psychomotor ability. At the age of 4 , children must be active in some activities that maximize their rough motoric and be brave to take a risk in a game (Masek \& Masduki, 2017). Based on the psychologist's research, at the age of 3 until 7, children have the highest activity level during their lives (Ghufron, Budiningsih, \& Hidayati, 2017; Normand \& Kohn, 2011).

In this level, the children's motoric coordination develops quickly and needs stimulation that can help them to evolve optimally. The psychomotor development is related to cognitive development. If children's psychomotor ability can be evolved optimally, so can their cognitive ability (Maslow, 1998). The stimulation by using physical activity can be implemented to support the learning process at the pre-operational stage (Rasyid, 2009). On the other hand, at the age of 4 to 7, children have their highest interest in mastering the new vocabulary. Children have interest in vocabulary when they start to communicate with their friends intensively (Kwan \& Wong, 2015). The interest in mastering vocabulary can be facilitated by implementing an active learning such as playing game individually and in a group (LeBarton, et al, 2015).

In terms of teaching vocabulary to the children, we need a good and detail preparation. (Stein, 2014). Teacher should know the kinds of vocabulary needed by the children.
The vocabulary itself must be considered in relation to their undestanding and experience (Stein, 2014). For children, it is better to teach simple vocabulary such as objects or things which are familiar for them (Hiebert $\&$ Kamil, 2005). So, the children do not only know the name of the object but also understand the concept and are able to describe the function. (Duff, et al., 2015). Furthermore, introducing nouns in teaching vocabulary to the children is based on their pre-operational stage (Scott \& Yteberg, 2002).

Using playing method to the students in elementary school will give a good implication for the success of learning purposes (Wright \& Buckby, 2006). Snowball throwing is a learning method that divides student into some groups. One group consists of 5 to 7 students. The member of each group will make a paper ball which contained English vocabulary that have been learned before (Susanty, 2016). The paper ball will be randomized and then one of the students in each group will take and throw it to his friend. The student who catches the ball will be pleased to open the paper ball and read the vocabulary in English, then tell the meaning in Bahasa. By using this method we can stimulate students' vocabulary mastery and psychomotor ability which is appropriate to their pre-operational stage (Pane \& Ernidawati, 2014).

Snowball throwing is a learning method that uses question ball which is made from a paper then shaped like a ball. The question ball will be thrown consecutively to the members of the group (Gani, Yusuf, \& Erwina, 2017). The question will be made by the students and it should be related to the material that has been learned before in order to stimulate students in expressing question based on the topic discussion (Aisyah, 2014; Sri Puji, 2015). Besides making questions, students are also trained to answer the questions from their friends properly (McCarten, 2007).

Snowball throwing method makes students be more active in learning process. This is based on the children's preoperational stage at the age of 4 to 7 (Sari, 
$\mathrm{dkk}, 2018$ ). According to the pre-operational stage, children will be more active in developing their psychomotor ability (Coady \& Huckin, 1997). By using the snowball throwing method, students can be facilitated to develop their psychomotor ability and also to master their English vocabulary.

Based on the beginning observation in SD Islam Terpadu Sorong City, the teachers still use conventional method in teaching English like memorizing. This method makes students not interested in and feel difficult in learning English vocabulary. That is why there are many students have lack participation in learning process. They tend to be sleepy or busy with unnecessary things such as playing with their friends or their stuff. It makes their learning outcomes score lower than the target. Related to the interview session, one of the students said that he did not have any interest in learning English and felt it difficult to remember the subject learned before.

The hypotheses in this research are:

$\mathrm{H}_{0} \mathrm{~A}$ : There is no influence of snowball throwing method to improve students' vocabulary mastery in the first grade of SD Islam Terpadu Sorong City.

$\mathrm{H}_{0} \mathrm{~B}$ : There is no influence of snowball throwing method to improve students' psychomotor ability in the first grade of SD Islam Terpadu Sorong City.

$\mathrm{H}_{1} \mathrm{~A}$ : There is an influence of snowball throwing method to improve students' vocabulary mastery in the first grade of SD Islam Terpadu -Sorong City.

$\mathrm{H}_{1} \mathrm{~B}$ : There is an influence of snowball throwing method to improve students' psychomotor ability in the first grade of SD Islam Terpadu Sorong City.

\section{Method}

This research is a quasi-experimental by using pre-post control group design (Shadish, Cook, \& Campbell, 2002). The population is the student at the first grade of
SD Islam Terpadu Sorong City which is consist of the boy and girl. The sampling technique in this research is stratified random sampling that takes the sample by considering the strata (level) in a population. The strata in this research is choosing the sample category based on the class (group) of the student. Randomized is used to decide the class category that will be taken as experiment and control group. This research is carried out in SD Islam Terpadu Sorong City.

This research started by doing an initial survey (Community, 2014; Nor Aishah, Salmah, \& Ravi, 2016; Owens, 2014) to know the learning method that has been implemented before in SD Islam Terpadu Sorong City. After that, the researcher randomized the class to choose the experiment and control group. Next, the researcher did the screening process to get the pretest score and then give the treatment to the experiment group by implementing snowball throwing while there is no treatment for the control group. Furthermore, these two groups will get the posttest to find out the alteration of each group.

About the pre-requisite test, the researcher used Shapiro Wilk for normality test and Levene for homogeneity test, while for the hypothesis test used was nonparametric technic Mann Whitney U Test to compare the condition between experiment and control group. The researcher also used Wilcoxon Signed Ranks Test to examine the internal changing in each group.

\section{Result and Discussion}

In this research, there are two kinds of instruments that have been validated by professional judgement. The first instrument includes the questions for pretest and posttest that use fill in the blank concept. The questions consist of 15 numbers with 5 questions about number, 5 questions about fruit and 5 questions about color. These three materials are based on English subject in the first grade (second semester) of Elementary School. The questions were made by the researcher and had been consulted for 
professional judgement as a practical education to make sure the suitability of the questions towards students' ability at the first grade of Elementary School.

Besides using questions, there is another instrument like psychomotor assessment that also has been validated by professional judgement. This psychomotor assesment used for examining student's psychomotor ability based on their accuracy in throwing the paper ball into the box. In making the psychomotor instrument, the researchers consulted with a psychologist, Aswendo Dwitantyanov, M.Psi., Psikolog., to validate the indicators that have been made before.

After giving the pretest, the researcher implemented snowball throwing as the treatment in experiment class. This treatment was done in 3 steps and ended by doing posttest. In the pretest session, there were two activities such as answering questions that consist of vocabulary matter. After that, the students were asked to throw a paper ball into a box. This activity was also carried out in post-test session.

Technically, there are 3 steps in treatment sessions such as learning the vocabulary, doing game simulation by using snowball throwing method and reflecting process. The difference in each step was based on the matterial in each treatment. For the first treatment (meeting), students learned about number starting from 1 until 10 , and for the second treatment they learn about 10 kinds of fruit such as, apple, banana, mango, papaya, orange, watermelon, avocado, grape, durian and coconut. The last, they studied about 10 kinds of colour such as black, purple, orange, green, red, brown, yellow, white, pink and blue.

According to the result in pre-test session, the data distribution was homogeneous but not normal. The normality test has been done by using Shapiro Wilk because this method can be used for limited subject. Based on the output of Shapiro Wilk, the significance assumption of vocabulary pretest for experiment group was 0,016 and for control group was 0,011; while the significance assumption of psychomotor pretest for exeperiment group was 0,004 and for control group was 0,006 . Related to the pretest data distribution, the significance score or $\mathrm{p}$ value was $<0,05$ (with the significance level 95\%).

After doing normality test, the researcher organized the homogeneity test. The researcher used levene test to make sure that the data were homogeneous. The result of levene test showed that the vocabulary mastery in pretest session was $0,996(>0,05)$ while the psychomotor ability was 0,561 $(>0,05)$. It means that the two variants (experiment and control group) were homogeneous. It happened because the student in Class IA and IB were similar. It can be seen based on their daily score and the result of pretest session quantitatively and qualitatively.

In line with the result of ranks analysis of the two groups, the average score of experiment group in vocabulary mastery posttest was bigger than control group $\left(\mathrm{K}_{\mathrm{e}}=\right.$ $39,74>K_{k}=15,26$ ). It also happened to the result of psychomotor test $\left(\mathrm{K}_{\mathrm{e}}=31,30>\mathrm{K}_{\mathrm{k}}=\right.$ 23,70 ), while the result of vocabulary mastery pretest beetwen experiment and control group was quatite similar $\left(\mathrm{K}_{\mathrm{e}}=27,81\right.$ and $\left.K_{k}=27,19\right)$, likewise the result of psychomotor pretest $\left(\mathrm{K}_{\mathrm{e}}=29,31\right.$ and $\mathrm{K}_{\mathrm{k}}=$ 25,69 ). It means that the average score of experiment group in vocabulary posttest was bigger than control group and it also was similar as the result of psychomotor test.

Table 1. Ranks

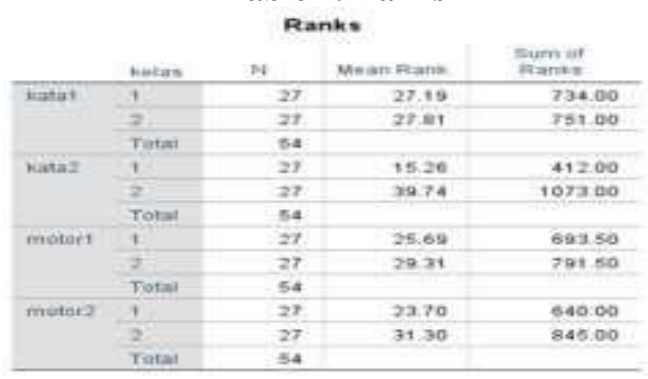


Based on the result of the vocabulary mastery post-test in experiment group, there was 1 out of 27 students who did not get the higher score or stagnant (the subject number 21). It was caused by the experiment subject who was not in a good condition at the second treatment (meeting), so, he could not follow the learning process optimally. The rest of 26 students got higher scores than before, moreover there were two students who got the highest score, where their score increased drastically up to 10 points (the subjects number 1 and 19).

If the result of vocabulary post-test in experiment group increased, it did not happen to the control group. Their score did not increase significantly. Based on the data distribution, there were 16 subjects had lower scores, they were the subjects number $2,4,5,6,7,8,10,15$, $16,18,19,21,22,25,26$, and 27. The lowest score starting from 1 until 4 points. Around 6 subjects had the stable score; they were the subjects of number $9,11,13,14,17$, and 20. Next, around 5 subjects had the increasing score; they were the subject number $1,3,12,23$, and 24. The highest score was 3 points by subject number 1 and 3 . Based on the statistic analysis, the vocabulary score in control group did not increase significantly.
Related to the data distribution on psychomotor test, there were 12 subjects who had the maximum score around 2 points, and 10 subjects who had the stable score between pretest and posttest. The subject who got the maximum score could be influenced by historical factor such as having social learning process from extranous variable. It also could be assumed by indirect interaction between the subject in experiment and control group. These conditions could not be controlled by the researcher that might influence the fluctuation of the students'scores.

On the other hand, there were 12 subjects in experiment group had the maximum score in psychomotor test (around 2 point), 12 subjects got the stable score and 3 subjects who had the lowest score. After doing Mann Whitney nonparametric test by considering the $\mathrm{Z}$ score, there was no significant alteration that happened to the psychomotor score in experiment and control group. The increasing of average score of psychomotor test in experiment group was more than control group, but, to find out whether the difference was significant or not, the researcher analyzed the significance coefficient ( $p$ value) by using Mann Whitney U Test.

Table 2. Mann Whitney U Test

\begin{tabular}{|c|c|c|c|c|}
\hline \multicolumn{5}{|c|}{ Test Statistics ${ }^{a}$} \\
\hline & katat & kataz & moter & motor2 \\
\hline Mann-Whitner UI & 356.000 & 34.000 & 315.500 & 262.000 \\
\hline Wileoron W & 734000 & 412,000 & 693.500 & 640.000 \\
\hline 2 & -148 & -5.736 & -894 & -1.945 \\
\hline Asyme, sig 2 -tated) & 882 & 000 & 372 & .052 \\
\hline
\end{tabular}

Based on the result of Mann Whitney $U$ Test, the U score of vocabulary mastery post-test was 34,000 and 262,000 for psychomotor. The $\mathrm{W}$ score for vocabulary mastery post-test was 412,000 and 640,000 for psychomotor. If converted into the $\mathrm{Z}$ score, the vocabulary mastery posttest was $-0,5736$ and $-1,945$ for psychomotor. The significance score ( $p$ value) of two tailed hypothesis test in vocabulary mastery post-test was 0,000 and 0,052 for psychomotor. It shows that, there was a significant difference between experiment and control group in vocabulary mastery post-test, but it did not happen to psychomotor ability. The next step was examining the alteration happened between pretest and post-test condition by using Wilcoxon Signed Ranks Test that had a part of 2 paired sample test. In this step, the researcher compared several conditions below:

a. The score of vocabulary mastery pretest in the control group will be compared to the score of vocabulary mastery post-test in control group.

b. The score of vocabulary mastery pretest in the experiment group will be compared to the score of vocabular mastery post-test in experiment group.

c. The score of psychomotor ability pretest in control group will be compared to the score 
of psychomotor ability post-test in control group.

d. The score of psychomotor ability pretest in experiment group will be compared to the score of psychomotor ability post-test in experiment group.

Based on the result, there was a significantly different score in experiment group. The score of vocabulary mastery was $(\mathrm{p}=0,000)$ and $(\mathrm{p}=$ $0,016)$ for psychomotor ability. It means that the result score of experiment group was lower than critical amount of the research 0,05 . So, it could be concluded that there was difference on significance score between the result of pretest and post-test of vocabulary mastery and psychomotor ability ( $\mathrm{H} 1$ is accepted). On the contrary, there was no difference on significance score in control group between the result of pretest and post-test of vocabulary mastery $(\mathrm{p}=0,081)$ and psychomotor ability $(\mathrm{p}=0,090)$. The result of Wilcoxon Signed Ranks test, shows as follows:

\section{Table 3. Wilcoxon Signed Ranks Test}

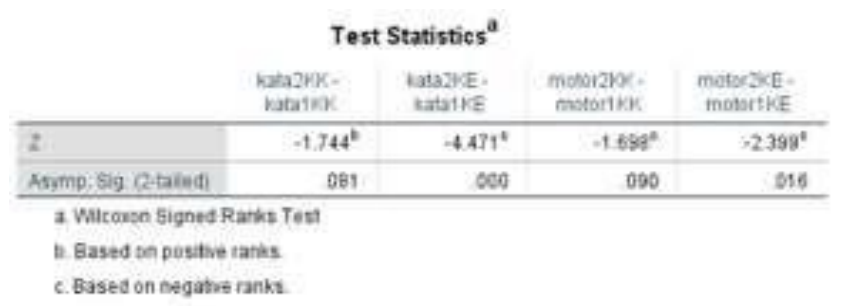

a. The comparison of $\mathrm{p}$ value (significance score) between the result of vocabulary mastery pretest and posttest in control group was $0,081(>0,05)$.

b. The comparison of $\mathrm{p}$ value (significance score) between the reult of vocabulary mastery pretest and post-test in experiment group was $0,000(<0,05)$.

c. The comparison of $\mathrm{p}$ value (significance score) between the result of psychomotor ability pretest and post-test in control group was $0,090(>0,05)$.

d. The comparison of $\mathrm{p}$ value (significance score) between the result of psychomotor ability pretest and post-test in experiment group was $0,016(<0,05)$.

Related to the explanation above, the significance score of vocabulary mastery $(\mathrm{p}=0,000)$ and psychomotor ability $(\mathrm{p}=0,016)$ in experiment group was lower than the critical amount of the research 0,05 , so, there was a difference on significance score between the result of pretest and posttest in vocabulary mastery and psychomotor ability (H1 is accepted). On the contrary, there is no difference of the significance score in control group between the result of pretest and post-test in vocabulary mastery $(\mathrm{p}=0,081)$ and psychomotor ability $(\mathrm{p}=0,090)$.

The unique thing happened to the psychomotor ability test. If we compare the result of psychomotor ability post-test in experiment and control group by using 2 paired independent sample Mann Whitney U Test $(p=$
0,052), there was no difference of the significance score between the experiment and control groups, while through Wilcoxon Signed Ranks Test, there was difference of the significance score between the result of post-test and pretest in experiment group $(p=0,016)$. The alteration that happened to experiment group in psychomotor aspect is quite significant. It can be illustrated, there was significance score in psychomotor aspect, even though it tends to be low. The researcher accepted the $\mathrm{H} 1$ and rejected the $\mathrm{HO}$ in measuring students' vocabulary mastery and psychomotor ability. Therefore, there was significant influence between the result of vocabulary mastery in experiment and control gorup $(\mathrm{p}=0,000<0,05)$, and significance score in psychomotor ability test $(\mathrm{p}=0,016>0,05)$.

Based on the explanation above, there was significant influence on the implementation of snowball throwing method towards students' vocabulary mastery and psychomotor ability. Therefore, snowball throwing can be used as a method to increase students' vocabulary mastery and psychomotor ability in learning English, but the method only increases the psychomotor ability in the low level and not faster than vocabulary mastery.

Psychomotor had complex characteristics, that was why we needed longer time and bigger frequency from the three meeting (treatment) in experiment group. The development of psychomotor ability could be applied by using another method that is more suitable or even by 
combining two different methods to improve students' psychomotor ability.

By considering the result of 2 paired sample test, the significance score of vocabulary mastery $(\mathrm{p}=0,000)$ and psychomotor ability $(\mathrm{p}=0,016)$ in experiment group was lower than the critical amount of the research 0,05 . It could be concluded that there was significance score between the result of pretest and posttest in vocabulary mastery and psychomotor ability (H1 is accepted). On the contrary, there was no significance score in the control group between the result of pretest and post-test in vocabulary mastery $(\mathrm{p}=0,081)$ and psychomotor ability in the control group. The chart below shows the result score of students' vocabulary mastery.

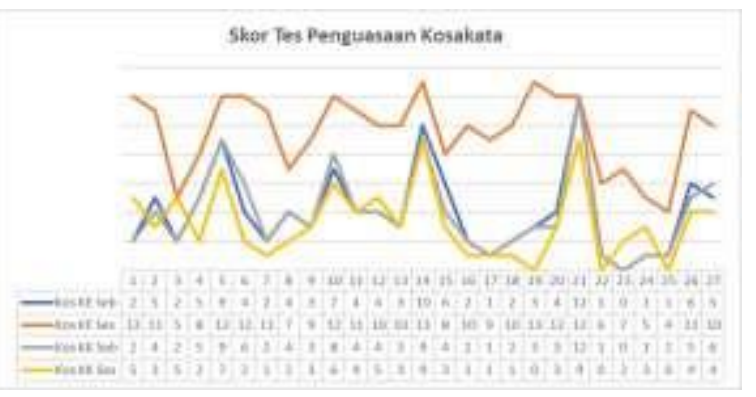

Figure 1. The Score of Vocabulary Mastery

The English vocabulary mastery could be improved by implementing snowball throwing method likewise the psychomotor ability, but it tends to be low. However, the result of hypothesis test showed the increasing score of vocabulary mastery and psychomotor ability.

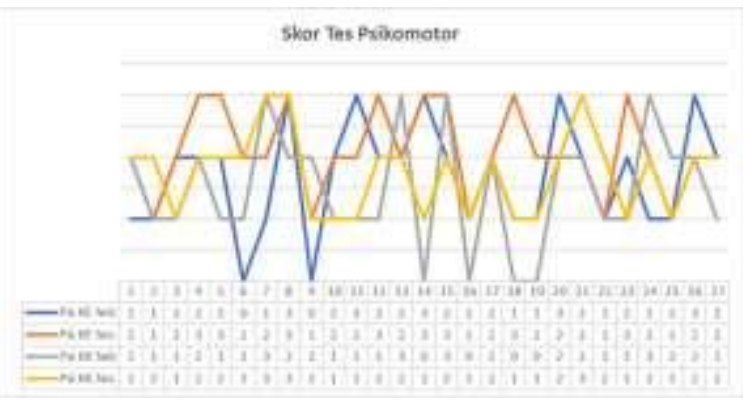

Figure 2. The score of Psychomotor Ability

\section{Conclusion}

Based on data analysis, the implementation of snowball throwing method in learning English had influence to improve students' vocabulary mastery and psychomotor ability in the first grade of SD Islam Terpadu Sorong City. Related to the result of 2 paired sample, the significance score of vocabulary mastery $(\mathrm{p}=0,000)$ and psychomotor ability $(\mathrm{p}=0,016)$ in experiment group was lower than the critical amount of the research 0,05 . We conclude that there was significance score between the result of pretest and post-test in vocabulary mastery and psychomotor ability (H1 is accepted). On the contrary, there was no significance score in control group between the result of pretest and posttest of vocabulary mastery $(\mathrm{p}=0,081) \quad$ and psychomotor ability $(\mathrm{p}=0,016)$.

Therefore, the comparison between the pretest and post-test score in measuring students' vocabulary mastery and psychomotor ability in experiment group was significantly different with control group. Related to the result of 2 paired sample test, there was increasing significance score in expereminet group before and after giving the treatment by using snowball throwing method. The result of data analysis showed that the $\mathrm{H} 1$ was accepted and the null hypothesis (H0) was declined.

Related to the explanation above, the implementation of snowball throwing method could improve students' vocabulary mastery and psychomotor ability in learning 
English at the first grade of SD Islam Terpadu-Sorong City. One of the reasons that caused the improvement of students' psychomotor tends to be low (eventhough the result is significant) was the time limit of the research and the lack of game simulation. In other words, the students' psychomotor ability could not be changed or improved in a short time because it would take longer time to train their motoric. On the other hand, the less subject also made the data not distributed normally. The total number of the first grade students in SD Islam Terpadu Sorong City was 54 that consist of two classes IA and IB, where each class contains of 27 sudents. It made the researcher have no choice to take all of the subjects.

\section{References}

Aisyah, A. R. (2014). Teaching and Learning At Personality Development Unit in the. International Journal of Education Research, 2(10), 203-214.

Alderson, J.C. \& Bachman, L. F. (2000). Assesssing Vocabulary. Cambridge Language

Assessment. Cambridge University Press.

Annisa, D. (2016). Penerapan Strategi Belajar Mnemonic dan Metode Snowball Throwing untuk Meningkatkan Motivasi dan Hasil Belajar Siswa IPA Pokok Bahasan Panca Indra Kelas IV di SDN Glanggang 1 Pasuruan Tahun Pelajaran 2015/2016.

Bandura, A. (1986). Social Foundation of Thought and Action: A Social Cognitive Theory. New York: Prentice Hall.

Berger, L. M., \& McLanahan, S. S. (2015). Income, relationship quality, and parenting: Associations with child development in two-parent families. Journal of Marriage and Family, 77(4), 996-1015.

Bloom, B., Englehart, Furst, Hill, dan Krathwohl. (1956).
Taxonomy
of
Educational
Objectives:
The Classification of

Educational Goals. Handbook I: Cognitive domain. New York: Longmans Green.

Burns, A., Freeman, D., \& Edwards, E. (2015). Theorizing and studying the language-teaching mind: Mapping research on language teacher cognition. The Modern Language Journal, 99(3), 585-601.

Coady, J. and Huckin, T. (1997). Second Language Vocabulary

Acquisition. Cambridge: Cambridge University Press.

Community, L. (2014). Principles of Survey Methodology. In Principles of Survey Methodology (pp. 1-65).

Dolati, Z., \& Tahriri, A. (2017). EFL Teachers' Multiple Intelligences and Their Classroom Practice. SAGE Open, 7(3), 1-12.

Duff, D., Tomblin, J. B., \& Catts, H. (2015). The influence of reading on vocabulary growth: A case for a Matthew effect. Journal of Speech, Language, and Hearing Research, 58(3), 853-864.

Ernawati, N. K. T., Murda, I. N., \& Rati, N. W. (2016). Penerapan Model Pembelajran Snowball Throwing Untuk Meningkatkan Motivasi Dan Hasil Belajar Ipa Siswa Kelas Iii Semester Genap Sdn 1 Tegal Badeng Timur Kecamatan Negara Kabupaten Jembrana Tahun Pelajaran 2015/2016. Mimbar Pgsd Undiksha, 4(1).

Fox, J.V.D. (2012). The Self-Actualizing Teacher. Improving College and University Teaching Journal. 13(3): 147-148.

Gani, S. A., Yusuf, Y. Q., \& Erwina, R. (2017). The Effectiveness Of Snowball Throwing Technique In Teaching Reading Comprehension. Proceedings of The 1st National Conference on Teachers' Professional, (October).

Ghufron, A., Budiningsih, A., \& Hidayati. (2017). model pembelajaran yang relevan digunakan untuk penanaman nilai-nilai budaya Yogyakarta adalah model pembelajaran non direktif versi 
Carl Rogers. Cakrawala Pendidikan: Jurnal Ilmiah Pendidikan, 2, 309-319.

Ghufron, A., Budiningsih, A., \& Hidayati. (2017). model pembelajaran yang relevan digunakan untuk penanaman nilai-nilai budaya Yogyakarta adalah model pembelajaran non direktif versi Carl Rogers. Cakrawala Pendidikan: Jurnal Ilmiah Pendidikan, 2, 309-319.

Gilman, L. (2012). The Theory of Multiple Intelligences. Indiana: Indiana University.

Hiebert, E. H. \& Kamil, M. L. (2005). Teaching and Learning Vocabulary: Bringing Research to Practice. Lawrence Erlbaum Associates Publisher: London.

Khanifatul. (2014). Pembelajaran Inovatif: Strategi Mengelola Kelas Secara Efektif dan Menyenangkan. Yogyakarta: Ar Ruzz Media.

Kwan, Y. W., \& Wong, A. F. (2015). Effects of the constructivist learning environment on students' critical thinking ability: Cognitive and motivational variables as mediators. International Journal of Educational Research, 70, 68-79.

LeBarton, E. S., Goldin-Meadow, S., \& Raudenbush,

S. (2015).

Experimentally induced increases in early gesture lead to increases in spoken vocabulary. Journal of Cognition and Development, 16(2), 199-220.

Masek, A., \& Masduki, M. (2017). Participation of Shy Children during the Teaching and Learning of Basic Psychomotor Skill. Pertanika Journal of Social Sciences \& Humanities.

Maslow, A.H. (1998). Toward a Psychology of Being (3rd Edition). New Jersey: Willey and Sons.

McCarten, J. (2007). Teaching Vocabulary. New York: Cambridg Universiti Press.

Nor Aishah, B., Salmah, I., \& Ravi, N. (2016). The Level of Intention in Formation the Entrepreneurship Career Choice Behavior among the Graduates
Entrepreneur Scheme Participants. National Conferences on Sustainable Cities 2016, (May), 109-116.

Normand, M. P., \& Kohn, C. S. (2011). Teach Your Children Well: a Review of Chance'S the Teacher'S Craft: the Ten Essential Skills of Effective Teaching. Journal of Applied Behavior Analysis, 44(2), 417-420.

Owens, L. K. (2014). Introduction To Survey Research Design. In Introduction To Survey Research Design (pp. 1-44).

Padmanabha, C. (2018). Critical Thinking: Conceptual Framework. Journal on Educational Psychology, 11(4).

Pane, I., \& Ernidawati, T. (2014). Improving The Students' Speaking Achievement in Narrative Text Through Snowball Throwing Model. GENRE Journal of Applied Linguistics of FBS Unimed, 3(1).

Paul Suparno. (2001). Teori Perkembangan Kognitif Jean Piaget. Yogyakarta: Kanisius.

Rasyid, Harun. (2009). Assesmen Perkembangan Anak Usia Dini. Yogyakarta: Multipresindo.

Santi, P. Y. P., Agustini, K., Si, S., Si, M., \& Divayana, D. G. H. (2016). Studi Komparatif Penggunaan Model Pembelajaran Group Investigation Dan Snowball Throwing Terhadap Motivasi Dan Hasil Belajar Pada Mata Pelajaran TIK Siswa Kelas X SMA Laboratorium Undiksha. Kumpulan Artikel Mahasiswa Pendidikan Teknik Informatika (ISSN: 2252-9063), 5(2).

Sari, S. A., Jasmidi, J., Kembaren, A., \& Sudrajat, A. (2018). The Impacts of Chemopoly-Edutainment to Learning Activities and Responses. Journal of Education and Learning, 12(2), 311318.

Sri Puji, A. (2015). Teachers' and students' perceptions of motivational teaching strategies in an Indonesian high school context. TEFLIN Journal, 24(1)(January), 14-31. 
Sumantri. (2005). Metode Keterampilan Motorik Anak Usia Dini. Jakarta: Diknas.

Susanty, H. (2016). Use Of The Snowball Throwing Technique For Teaching Better ESL Speaking. English Education journal, 7(1), 117-129.

Scott, W. A. and Ytreberg, E. H. (2002). Teaching English to Children. Longman Ldt.

Shadish, Cook, dan Campbell. (2002). Experimental and QuasiExperimental Design for Generalized Causal Inference. Boston: Houghton Mifflin Company.

Smith, Mark K. (2002). Howard Gardner, multiple intelligences and education. In The encyclopedia of informal education. Boston: Harvard University Press.

Stein, M.I. (2014). Stimulating Creativity: Individual Procedures. London: Academic Press Inc. Ltd.

Susanty, H. (2016). Use of the Snowball Throwing Technique for Teaching
Better ESL Speaking. English Education Journal, 7(1), 117-129.

Tojo, H., \& Takagi, A. (2017). Trends in Qualitative Research in Three Major Language Teaching and Learning Journals, 2006-2015. International Journal of English Language Teaching, 4(1), 37.

Wheatley, K.F. (2005). The Case for Reconceptualizing Teacher Efficacy Research. Teaching and Teacher Education. 21: 747-766.

Woolfolk, A., dan Davis. (2005). Teachers' Sense of Efficacy and Adolescent Achievement. In $\mathrm{T}$. Urdan \& F. Pajares (Eds.). Adolescence and Education. 5: 117137. Greenwich, CT: Information Age.

Wright, A., Betteridge, A. \& Buckby, M. (2006). Games for Language Learning. New York: Cambridge Universiti Press. 